\title{
Estrogen Receptors and the Regulation of Neural Stress Responses
}

\author{
Robert J. Handa ${ }^{a}$ Shaila K. Mani ${ }^{b}$ Rosalie M. Uht ${ }^{c}$ \\ a Department of Basic Medical Sciences, University of Arizona College of Medicine - Phoenix, Phoenix, Ariz., \\ ${ }^{b}$ Department of Molecular and Cellular Biology, Baylor College of Medicine, Houston, Tex., and ' Deparment of \\ Pharmacology and Neuroscience and the Institute for Aging and Alzheimer's Disease Research, University of \\ North Texas Health Sciences Center, Fort Worth, Tex., USA
}

\section{Key Words}

Estradiol $\cdot$ Hypothalamus $\cdot$ Pituitary $\cdot$ Behavior $\cdot$ Anxiety

\begin{abstract}
It is now well established that estrogens can influence a panoply of physiological and behavioral functions. In many instances, the effects of estrogens are mediated by the 'classical' actions of two different estrogen receptors (ERs), ER $\alpha$ or ERß. ER $\alpha$ and ERß appear to have opposing actions in the control of stress responses and modulate different neurotransmitter or neuropeptide systems. Studies elucidating the molecular mechanisms for such regulatory processes are currently in progress. Furthermore, the use of ER $\alpha$ and ER $\beta$ knockout mouse lines has allowed the exploration of the importance of these receptors in behavioral responses such as anxiety-like and depressive-like behaviors. This review examines some of the recent advances in our knowledge of hormonal control of neuroendocrine and behavioral responses to stress and underscore the importance of these receptors as future therapeutic targets for control of stress-related signaling pathways.
\end{abstract}

Copyright $\odot 2012$ S. Karger AG, Basel

\begin{tabular}{ll}
\hline KARGER & $\oplus$ 2012 S. Karger AG, Basel \\
Fax +41 61 306 12 34 & 0028-3835/12/0962-0111\$38.00/0 \\
$\begin{array}{l}\text { E-Mail karger@karger.ch } \\
\text { www.karger.com }\end{array}$ & $\begin{array}{l}\text { Accessible online at: } \\
\text { www.karger.com/nen }\end{array}$
\end{tabular}

\section{Introduction}

Estrogens influence both reproductive- and nonreproductive-related neurobiological functions. Given that the brains of both males and females are exposed to varying amounts of estrogens, as a result of either gonadal secretions or local synthesis from androgenic precursors, deciphering the role of estrogens in brain function is important in understanding normal physiology as well as pathological responses. Recent studies indicate novel roles for estrogens in the regulation of neuroendocrine, autonomic and behavioral responses to stress. In this regard, estrogens have also been shown to modulate related functions such as inflammatory processes, pain, anxiety, depressive-like behaviors and cognitive function [1-4]. In this review, we focus on some of the roles for estrogens and estrogen receptors (ERs) in the control of stress and stressrelated behaviors and address a few of the molecular mechanisms that might drive these regulatory processes.

\section{ERs in the Brain}

The actions of estrogens are mediated by at least two different ERs. Currently, the two major types of ERs described are ER $\alpha$ (also known as ESR1 or NR3A1) and 
ER $\beta$ (also known as ESR2 or NR3A2). Of these two receptors, ER $\alpha$ was the original ER to be identified and cloned [5], whereas ER $\beta$ was not described until the subsequent decade [6]. Both receptors share considerable homology within the ligand-binding and DNA-binding domains and, in similar fashion to all members of the nuclear receptor superfamily of proteins, act as ligand-activated transcription factors. These receptors are characterized by their ability to alter transcriptional activity by binding to estrogen response elements (EREs) in the DNA sequence of gene promoters, thereby providing a direct link between steroid signals and transcriptional responses (for review, see [7]).

It has now become apparent that nonclassical, or 'rapid', estrogen actions also occur in the brain and are mediated by extranuclear estrogen receptors $[8,9$, for review see 10,11$]. E R \alpha$ and $E R \beta$ have been found in the plasma membrane and cytoplasm where they can regulate intracellular signaling pathways through phosphorylation events $[12,13]$. Other receptor proteins, such as GPR30 [14], a $G$ protein-coupled receptor that binds estradiol with high affinity, or a yet to be described $G$ protein-coupled receptor for the diphenylacrylamide, STX [15], have also been suggested as functional receptors that transmit rapid actions of estrogens through second messenger pathways. However, these nonclassical actions of steroid hormones can also result in gene expression changes [16], underscoring the complex relationship between the rapid and genomic actions of $\mathrm{ER} \alpha$ and $\mathrm{ER} \beta$.

In the mammalian nervous system, $\mathrm{ER} \alpha$ and $\mathrm{ER} \beta$ are expressed differentially throughout the brain and spinal cord where they have unique but overlapping expression patterns. Of importance for this review, brain regions such as the preoptic area, bed nucleus of the stria terminalis and medial amygdala, express both ER types. ER $\alpha$ is the predominant receptor found in the ventromedial nucleus of the hypothalamus, whereas ER $\beta$ is the predominant form found in the suprachiasmatic, supraoptic and paraventricular hypothalamic nuclei [17-19]. The results of these anatomical studies emphasize the fact that $\mathrm{ER} \alpha$ and $\mathrm{ER} \beta$ can affect numerous complex physiological and behavioral functions of animals.

An interesting and perhaps confounding aspect of ERs is the fact that they are variably spliced under normal and pathological conditions. Several splice variants of ER $\alpha$ have been identified, although most of these have been found in carcinomas and peripheral reproductive tissues $[20,21]$. Prior to the discovery of ER $\beta$, an ER variant (likely ER $\alpha$ ) lacking the 4th exon was described in rodent brain [22]. A 52-kDa ER $\alpha$ variant of unknown etiology has been found in plasma membrane of neurons [23], and several ER $\alpha$ splice variants have been described in human brain [24].

For ER $\beta, 6$ splice variant mRNAs have been shown in rodents, including the originally described wild-type (WT) form (designated ER $\beta 1$; $[25,26])$. Alternative splicing of the 8 exons encoding ER $\beta$ result in transcripts that have an additional 18 amino acids in the ligand-binding domain (ER 32$)$ or a deletion of exon 3, encoding the 39 amino acids in the carboxy terminus of the DNA-binding domain $(E R \beta-\delta 3)$, or exon $4(E R \beta-\delta 4)$. Combinations of the delta variants with ER $\beta 1$ and ER $\beta 2$ result in $\beta 1 / \delta 3$, $\beta 2 / \delta 3, \beta 1 / \delta 4$ and putatively $\beta 2 / \delta 4$. Each of these splice variants alters the binding affinity, association kinetics, cellular trafficking and transcriptional efficacy of the receptor, thus providing functional diversity to ER $\beta$ signaling [25-28]. To date, the mRNAs of these splice variants have been shown in multiple tissue, including brain, with levels of some splice variants sometimes exceeding that of the native ER $\beta 1$ type [25-27]. Unfortunately, the ability to detect protein levels of the specific ER $\beta$ variants has been hampered by the inability to generate specific antibodies against the exon-deletion variants. Antipeptide antibodies have been generated against the unique sequence in the ligand-binding domain of $\operatorname{ER} \beta 2[29,30]$. Mapping studies in brain have shown that ER $\beta 2$ has a distribution that largely matches ER $\beta 1$ with high amounts in the cortex, raphe and supraoptic nucleus [30].

\section{ERs and the Hypothalamo-Pituitary-Adrenal Axis}

The hypothalamo-pituitary-adrenal (HPA) axis consists of a cascade of neural and humoral signals driven by both the circadian pacemaker as well as the environment. Changing environmental conditions or perceived threats to homeostasis activate the HPA by funneling information through neurons located in the paraventricular nucleus (PVN) of the hypothalamus, a brain region that integrates multiple positive and negative inputs. Central to HPA axis regulation are neurons in the parvocellular part of the PVN that express corticotropin-releasing hormone (CRH). The release of CRH into the hypophyseal portal vasculature enhances the synthesis and release of adrenocorticotropic hormone (ACTH) from the anterior pituitary. $\mathrm{CRH}$ is the most potent ACTH secretagogue and its actions at the anterior pituitary can be enhanced by other hypothalamic factors such as vasopressin and oxytocin $[31,32]$. In turn, ACTH acts on the adrenal cortex to stimulate the synthesis and secretion of corticosterone 
(CORT). Circulating CORT subsequently feeds back at the level of the pituitary, hypothalamus and higher brain areas to limit further hormone secretion $[33,34]$.

Over the years, multiple studies have demonstrated that estradiol, or the activation of ERs, can influence HPA responses to stress. Early studies, such as those by Gaskin and Kitay $[35,36]$, demonstrated that sex steroid hormones could modulate adrenal function. In many cases, ovariectomy reduced, whereas estradiol treatment of gonadectomized females enhanced, the HPA responsivity to a stressor [36-39]. However, studies suggesting that estradiol treatment can inhibit HPA activity have also been reported $[40,41]$. Whether such discrepancies are due to estradiol acting at different levels of the HPA axis, the amplitude or duration of hormone exposure, or the length of time following ovariectomy remains to be determined [39-41]. Importantly, recent studies have also demonstrated that selective activation of ER $\alpha$ can amplify HPA reactivity to stress, whereas selective activation of ER $\beta$ can reduce the reactivity of the HPA axis to stressors [42, 43]. Curiously, the cellular mechanisms whereby a single hormone, such as estradiol, that binds ER $\alpha$ and ER $\beta$ with near equivalent affinities can selectively increase or decrease HPA reactivity under physiological conditions remains to be determined.

\section{ER $\alpha$ and the HPA Axis}

$\mathrm{ER} \alpha$ is found at low levels in rodent PVN neurons [4446] and although some increases have been noted under conditions such as fasting [46], the distribution suggests the possibility of an indirect mode of estradiol action on PVN responses to stress. In support of this, Weiser and Handa [47] have shown that ER $\alpha$ is expressed by GAD67ir neurons in the peri-PVN region of the hypothalamus, placing these neurons in a strategic position to modulate HPA axis function through transsynaptic mechanisms. GAD67 is a rate-limiting enzyme for the production of GABA, and GABA-a receptor blockade can increase CRH expression in the PVN [48]. Indeed, glucocorticoid inhibition of PVN activity is also mediated through increased GABA release onto parvocellular neurons of the PVN [49]. Further, the administration of estradiol and $\mathrm{ER} \alpha$ agonists can impair glucocorticoid receptor-mediated negative feedback regulation of the HPA axis when implanted adjacent to the PVN [47], thereby implicating these neurons in ER $\alpha$ regulation of HPA function. Accordingly, it has been suggested that ER $\alpha$ enhancement of HPA axis function may work through a reduction in inhibitory tone normally provided by GABAergic neurons that surround the PVN [47].

\section{$E R \beta$ and the HPA Axis}

In contrast to $E R \alpha, E R \beta$ is expressed at high levels by neurons within the PVN [44]. A large number of PVN ER $\beta$ cells are oxytocin (OT)- and vasopressin (AVP)-immunoreactive [44, 50-52]. CRH neurons of the PVN also express ER $\beta$, although to a much lesser extent than do AVP and OT neurons $[44,53,54]$. Further, both OT and AVP can be colocalized with CRH in some parvocellular neurons of the PVN [55-57]. Stimulation of parvocellular neurons also causes the dendritic release of OT and AVP within the PVN, which works to inhibit CRH secretion [58]. The high levels of ER $\beta$ in the PVN suggest that estradiol could directly alter the function of PVN neuropeptide neurons. Indeed, a central, PVN, site of action in the regulation of HPA reactivity has been demonstrated by the studies of Lund et al. [42] who placed ER $\beta$ agonists in an area adjacent to the PVN and demonstrated a reduction of stress-responsive CORT and ACTH secretion in ovariectomized female rats. Furthermore, compounds with selective affinity for ER $\beta$, such as diarylpropionitrile (DPN), WAY-200070 or $3 \beta$-diol, whether delivered centrally or peripherally, appear to inhibit HPA reactivity to stressors [42] as well as reduce activation of neuropeptide neurons in the PVN, as demonstrated by altered expression of $c$-fos [43].

\section{Molecular Mechanisms of ER Signaling: Controlling crh through Alternate Pathways}

In vivo, $\mathrm{CRH}$ neurons can be considered a prototypic example of a systems integrator, incorporating large amounts of information from various sensory inputs to control a specific neuroendocrine or autonomic output. Elucidating the detailed molecular mechanisms whereby a single input, such as estradiol, can modulate crh expression is necessary for a complete understanding of the manner by which $\mathrm{CRH}$-expressing neurons integrate information. In this case, salient information to CRH neurons concerning reproductive status is necessary given the close association between level of stress reactivity and reproductive success. Importantly, the analysis of integration at the molecular level initially requires simpler systems than in vivo models.

\section{ER Regulation through Alternate Pathways}

The prototypic pathway for an estrogen to exert its effect involves its binding to an ER with the resultant holoreceptor subsequently binding to specific sites in DNA. In the case of ERs, this 'classic' mode of action involves

Neuroendocrinology 2012;96:111-118 
binding to palindromic EREs that regulate genes in cis. In addition to this mode of regulation, ERs regulate expression by recruiting other transcription factors and/or shared coregulatory proteins. This trans mode of regulation, is generally referred to as regulation via an 'alternate pathway' [59] or one that involves a 'tethering' response element [60]. For the ER, such regulation has been demonstrated for multiple transcription factors, two of the best described being AP-1 and Sp1 [59, 61]. Given that the crh promoter does not have a full palindromic ERE, thereby precluding a 'classic' mechanism of action, an appreciation of alternate pathways is critical for understanding the regulatory mechanisms of crh expression. To this end a number of cell-based techniques have been used for examining $\mathrm{CRH}$ regulation by estradiol. The earliest of these were performed by Vamvakopoulos et al. [62]. Given the absence of an ERE in the crh promoter, the investigators focused on $3^{\prime}$ ERE half-sites. These initial analyses of estrogen-regulated crh expression used transient cotransfections of nonneuronal CV-1 cells with ER $(\alpha)$ and crh:reporter constructs [62], and showed that treatment with estradiol led to an approximate twofold increase in $\mathrm{crh}$ promoter activation.

After the discovery of ER-mediated alternate pathways (e.g. $[59,63])$, and the discovery of ER $\beta$ and ER $\beta$ splice variants, ER regulation of $c r h$ promoter expression was reassessed. Using reporter-based assays in $\mathrm{HeLa}$ cells, Miller et al. [54] focused on estrogen regulation of a more proximal region of $c r h$ promoter activity. Because the existence of alternate pathways had been well established by then, it was logical to examine the proximal promoter even in the absence of either a palindromic ERE or an ERE half-site. Experiments were carried out in the presence of estradiol or tamoxifen. The latter was used to assess whether an alternate pathway was in play [64]. ER $\alpha$ activated the $c r h$ promoter weakly in the presence of either ligand. In contrast, the ER $\beta$ splice variants activated crh expression more robustly. Furthermore, each of the ER $\beta$ splice variants exhibited a different profile of response. The ER $\beta 1 / \delta 3$ variant was most potent, increasing activation by about 12 -fold in the presence of estradiol. Thus, it is clear that ER $\beta$ is able to play a significant role in $c r h$ promoter activity and can do so in the absence of palindromic EREs.

At the time, a critical component of cell-based experiments was missing, i.e. the availability of well-characterized neural cell lines that express CRH. Currently, there are a number of hypothalamic cell lines derived from rodents, which have been characterized with respect to their neuropeptidergic phenotype $[65,66]$. One such line,
IVB, derived from rat embryo hypothalami, has many characteristics of paraventricular parvocellular neurons that express CRH and regulate the HPA axis [65]. These characteristics include the ability to synthesize and secrete $\mathrm{CRH}$, express glucocorticoid receptors and reduce crh expression in response to glucocorticoid treatment. Thus, they provide a good model system for determining mechanisms of $c r h$ expression. The IVB line has proved suitable for analyzing estrogen regulation of $c r h$ expression, as well. The line expresses ER $\alpha$ and ER $\beta$ as detected by immunocytochemistry (Gregg and Uht, unpubl.) and functional ERs as measured by crh reporter assays [67].

One seeming incongruity in the use of IVB cells is that they express both $\mathrm{ER} \alpha$ and $\mathrm{ER} \beta$, whereas in vivo data suggests the possibility that ER $\alpha$ effects on PVN function are indirect and mediated through GABArgic interneurons [47]. This does not rule out direct effects of ER $\alpha$ in other $\mathrm{CRH}$ neurons, such as those found in the central nucleus of the amygdala or elsewhere [68]. Moreover, it is important to consider that every cell has the potential to express a given protein and what is not apparent in a given in vivo state does not preclude its being expressed in another. For example, $\mathrm{CRH}$ and AVP are expressed in the PVN at rather low levels in the presence of endogenous glucocorticoids, but expression can be greatly increased following removal of glucocorticoids, such as after adrenalectomy $[69,70]$. Moreover, following kainate-induced seizures, $\mathrm{CRH}$ expression is induced in areas such as the piriform and cingulate cortices, bed nucleus of the stria terminalis and globus pallidus at relatively high levels [71]. Similarly, although ER $\alpha$ is minimally expressed in PVN neurons, Estacio et al. [46] have shown that following a 48-hour fast, the number of ER $\alpha$ containing neurons in the PVN and $\mathrm{A} 2$ region of the nucleus of the solitary tract (NTS) increased significantly. Unfortunately, the phenotype of these new ER $\alpha$-expressing neurons has never been determined, which leaves open the possibility that, under certain circumstances, PVN CRH neurons may express ER $\alpha$.

\section{Kinetics of Chromatin Occupancy}

Kinetic approaches for examining promoter occupancy have been performed for several transcription factors and coregulators including ER $\alpha$ [72-74]. In 2003, Metivier et al. [75] published a comprehensive kinetic report of cyclic occupancy of the pS2 promoter region by ER $\alpha$ and identified proteins with which it might form a regulatory complex. The data permitted modeling of regulatory complex assembly and disassembly.

Such an approach has been reported for analysis of $\mathrm{crh}$ regulation in an amygdalar cell line that expresses $\mathrm{CRH}$ 
[76]. These data permit predictions of ER complexes with coregulators. Specifically, at $1 \mathrm{~min}$ ER $\alpha$ co-occupies the promoter with SRC-1. By 3 min the putative ER $\alpha / S R C-1$ complex no longer predominates. Rather, ER $\beta$ co-occupies the promoter with CBP. The occupancy of the two complexes together corresponds to the kinetic profile of $\mathrm{CRH}$ mRNA levels. Individually, they do not. The importance here is that if taken alone, the mRNA data could suggest that there is one mechanism involved in the $\mathrm{E}_{2}$ response. With an evaluation of occupancy, it is clear that that is not the case. That the two putative complexes are functionally distinct is suggested by an increased acetylation of histone 3 in the case of ER $\alpha$ and of histone 4 in the case of ER $\beta$.

In summary, molecular regulation through alternate pathways and phasic occupancy of the crh promoter may play significant roles for integrating incoming information, such as a change in reproductive state, to adjust stress reactivity and autonomic function. Certainly, changing the gain of stress responses across the reproductive cycle is likely a necessary component for controlling appropriate behaviors and physiological functions, thereby ensuring reproductive success.

\section{ERß and Stress-Related Behaviors}

In addition to effects on stress responsive hormone secretion, estrogens modulate several nonreproductive functions including mood, fear, anxiety, depression, cognition and memory in both humans and laboratory animals [77-79]. Depending on multiple factors, such as age and stage of the reproductive cycle, estrogens have been reported to exhibit either anxiogenic or anxiolytic properties in rodents. Elevated levels of estradiol during proestrus or estradiol replacement to ovariectomized females elicit anxiolytic actions [37, 80, 81]. Removal of endogenous estrogens by ovariectomy enhances anxiety-like behaviors, while estradiol replacement has been reported to increase or decrease behavioral measures of anxiety in rodents [82].

A large body of evidence suggests that ER $\beta$ mediates estradiol's anxiolytic functions in the central nervous system [83-86]. In ovariectomized female rats, pharmacological administration of the ER $\beta$-specific agonist DPN, but not the ER $\alpha$-specific agonist propyl-pyrazoletriol, decreased anxiety-related behaviors measured in the open-field arena, elevated plus maze (EPM) and lightdark box [87]. In addition to decreased anxiety in the open field, DPN-administration also resulted in less de- pressive-like behavior in the forced swim test $[88,89]$. DPN administration not only attenuates anxiety-like behaviors in ovariectomized rats, but also causes a reduction in stress-induced reactivity of the HPA axis [43]. This reduction in stress reactivity is reflected by a decrease in plasma CORT and ACTH levels and immediate early gene activation of $c$-fos in the PVN of the hypothalamus, a brain region containing some of the highest levels of ER $\beta$ expression. Administration of the nonselective ER antagonist tamoxifen blocks the inhibitory actions of DPN, confirming the role of ER $\beta$ in the modulation of stress reactivity [43].

Using gonad-intact female mice with a disruption of the gene for either $\mathrm{ER} \alpha(\mathrm{ER} \alpha \mathrm{KO})$ or $\mathrm{ER} \beta$ ( $\beta E R K O)$, Krezel et al. [90] demonstrated increased anxiogenic behaviors by $\beta E R K O$ mice compared to their WT littermates or ER $\alpha$ KO mice. Further, DPN administration to ovariectomized females increased open-field entries and the time spent in open arms in plus maze in WT mice, but not the $\beta E R K O$ mice, suggesting a role for ER $\beta$ in anxiety responses [91]. Hughes et al. [92] have also demonstrated a role for ER $\beta$ in modulation of anxiety and depression using another ER $\beta$ selective agonist, WAY200070 (Wyeth, Princeton, N.J., USA) in gonadectomized male $\beta E R K O$ and WT littermates. Interestingly, ER $\beta$ modulation of anxiety also appears to involve serotonin and dopamine neurotransmission [92-94].

Although ER $\beta$-specific agonists and $\beta E R K O$ mice have provided substantial proof of involvement of ER $\beta$ in anxiety behaviors, the mechanism(s) by which the ER $\beta$ containing neurons in neuroendocrine stress circuitry function to modulate stress responses are still unclear. Using S-DPN, a more selective enantiomer of the commonly used racemic-DPN, as a pharmacological tool in conjunction with $\beta E R K O$ mice, we recently examined ER $\beta$ action on anxiety-related behavioral measures, the corresponding stress hormonal response to HPA axis reactivity and neuroanatomical targets of ER $\beta$ action. Peripheral administration of S-DPN decreased anxiety-like behaviors in open-field activity, light/dark exploration and EPM in ovariectomized WT female mice, but not $\beta E R K O$ female mice. S-DPN treatment also resulted in a significant decrease in plasma CORT and ACTH levels in WT, but not in $\beta E R K O$ mice. Such decreases in CORT and ACTH secretion in WT animals have also been reported upon administration of ER $\beta$ selective agonists, racemic DPN, WAY-200070 and SDPN $[43,87,92]$.

Increased $c$-fos mRNA expression was observed in the anterior dorsal part of the medial amygdala and bed nu- 
cleus of the stria terminalis regions in S-DPN-treated WT mice, but not in $\beta E R K O$ mice exposed to the EPM [95]. Similar activation of $c$-fos expression in the amygdala has also been reported in rats exposed to the EPM [96]. The absence of changes in $c$-fos expression in the PVN region by S-DPN in WT mice suggests the possibility that ER $\beta$ mediated effects on parvocellular neurons of the PVN may not be direct, but indirect. This latter possibility is supported by the reduced HPA axis reactivity by the ER $\beta$ agonist in WT mice, following EPM. Taken together, the available data suggest that $\mathrm{ER} \beta$ activates an inhibitory circuit within the amygdala and extended amygdala that can then elicit reduced activation of outputs regulating anxiogenic responses. Further studies are in progress to determine the complexity of ER $\beta$ regulation in stress reactivity.

\section{Conclusion}

It has become increasingly evident that estrogens can profoundly affect neuroendocrine and behavioral responses to stress. The effects of estrogens are mediated by classical estrogen receptors, ER $\alpha$ and ER $\beta$. Furthermore, in most cases, these receptors influence neuroendocrine function and behavior by differing mechanisms of action. In regards to neuroendocrine responses, ER $\alpha$ and ER $\beta$ work in opposition through different populations of neurons within or near the PVN. Increasing evidence supports the direct regulation of neuropeptide promoters, such as $c r h$, by ER $\beta$. For behavioral responses, ER $\beta$ appears to work through brain circuitry involving the amygdala. Further work is still required, however, to tease out the exact cellular and molecular mechanisms that are used by ER $\alpha$ and $\operatorname{ER} \beta$ to regulate stress responses. Nonetheless, ER $\alpha$ and ER $\beta$ appear to be logical therapeutic targets for treatment of dysfunctional HPA regulation and anxiety.

\section{Acknowledgements}

Research in the authors' laboratories are funded by grants from the National Institutes of Health: R01-NS039951 (R.J.H.), R01 HD062512 (S.K.M.) and R01 MH82900 (R.M.U.); and the National Science Foundation: IOS-0937331 (S.K.M.).

\section{References}

1 Sárvári M, Hrabovszky E, Kalló I, Solymosi N, Tóth K, Likó I, Széles J, Mahó S, Molnár B, Liposits Z: Estrogens regulate neuroinflammatory genes via estrogen receptors $\alpha$ and $\beta$ in the frontal cortex of middle-aged female rats. J Neuroinflammation 2011;8:82.

-2 Hunter DA, Barr GA, Amador N, Shivers KY, Kemen L, Kreiter CM, Jenab S, Inturrisi CE, Quinones-Jenab V: Estradiol-induced antinociceptive responses on formalin-induced nociception are independent of COX and HPA activation. Synapse 2011;65:643-651.

-3 Diz-Chaves Y, Kwiatkowska-Naqvi A, Von Hülst H, Pernía O, Carrero P, Garcia-Segura LM: Behavioral effects of estradiol therapy in ovariectomized rats depend on the age when the treatment is initiated. Exp Gerontol 2012; 47:93-99.

4 Kiss A, Delattre AM, Pereira SI, Carolino RG, Szawka RE, Anselmo-Franci JA, Zanata SM, Ferraz AC: $17 \beta$-Estradiol replacement in young, adult and middle-aged female ovariectomized rats promotes improvement of spatial reference memory and an antidepressant effect and alters monoamines and BDNF levels in memory- and depression-related brain areas. Behav Brain Res 2012;227:100-108.

5 Walter P, Green S, Greene G, Krust A, Bornert JM, Jeltsch JM, Staub A, Jensen E, Scrace $\mathrm{G}$, Waterfield M, Chambon P: Cloning of the human estrogen receptor cDNA. Proc Natl Acad Sci USA 1985;82:7889-7893.
-6 Kuiper GG, Enmark E, Pelto-Huikko M, Nilsson S, Gustafsson JA: Cloning of a novel receptor expressed in rat prostate and ovary. Proc Natl Acad Sci USA 1996;93:5925-5930.

$\checkmark 7$ Robinson-Rechavi M, Garcia HE, Laudet V: The nuclear receptor superfamily. J Cell Sci 2003; 116:585-586.

$>8$ McEwen BS, Alves SE: Estrogen actions in the central nervous system. Endocr Rev 1999;20:279-307.

$\checkmark 9$ Milner TA, Lubbers LS, Alves SE, McEwen BS: Nuclear and extranuclear estrogen binding sites in the rat forebrain and autonomic medullary areas. Endocrinology 2008;149: 3306-3312.

10 Micevych PE, Kelly MJ: Membrane estrogen receptor regulation of hypothalamic function. Neuroendocrinology 2012;96:103-110.

11 Simpkins JW, Singh M, Brock C, Etgen AM: Neuroprotection and estrogen receptors. Neuroendocrinology 2012;96:119-130.

12 Micevych PE, Mermelstein PG: Membrane estrogen receptors acting through metabotropic glutamate receptors: an emerging mechanism of estrogen action in brain. Mol Neurobiol 2008;38:66-77.

13 Kelly MJ, Ronnekleiv OK: Control of CNS neuronal excitability by estrogens via membrane-initiated signaling. Mol Cell Endocrinol 2009;308:17-25.
14 Revankar CM, Cimino DF, Sklar LA, Arterburn JB, Prossnitz ER: A transmembrane intracellular estrogen receptor mediates rapid cell signaling. Science 2005;307:1625-1630.

15 Qiu J, Ronnekleiv OK, Kelly MJ: Modulation of hypothalamic neuronal activity through a novel G-protein-coupled estrogen membrane receptor. Steroids 2008;73:985-991.

16 Vasudevan N, Pfaff DW: Non-genomic actions of estrogens and their interaction with genomic actions in the brain. Front Neuroendocrinol 2008;29:238-257.

17 Laflamme N, Nappi RE, Drolet G, Labrie C, Rivest S: Expression and neuropeptidergic characterization of estrogen receptors (ERalpha and ERbeta) throughout the rat brain: anatomical evidence of distinct roles of each subtype. J Neurobiol 1998;36:357-378.

18 Osterlund M, Kuiper GG, Gustafsson JA, Hurd YL: Differential distribution and regulation of estrogen receptor-alpha and -beta mRNA within the female rat brain. Brain Res Mol Brain Res 1998;54:175-180.

19 Shughrue PJ, Lane MV, Merchenthaler I: Comparative distribution of estrogen receptor-alpha and -beta mRNA in the rat central nervous system. J Comp Neurol 1997;388: 507-525.

20 Ferro P, Folani A, Muselli M, Pfeffer U: Alternative splicing of the human estrogen receptor alpha primary transcript: mechanisms of exon skipping. Int J Mol Med 2003; 12:355-363. 
21 Marshburn PB, Zhang J, Bahrani-Mostafavi Z, Mostafavi BZ, Marroum MC, Mougeot JL, Roshon MJ: Estrogen receptor-alpha messenger RNA variants that lack exon 5 or exon 7 are coexpressed with wild-type form in human endometrium during all phases of the menstrual cycle. Am J Obstet Gynecol 2004; 191:626-633.

-22 Skipper JK, Young LJ, Bergeron JM, Tetzlaff MT, Osborn CT, Crews D: Identification of an isoform of the estrogen receptor messenger RNA lacking exon four and present in the brain. Proc Natl Acad Sci USA 1993;90:71727175.

-23 Sominguez R, Micevych P: Estradiol rapidly regulates membrane estrogen receptor alpha levels in hypothalamic neurons. J Neurosci 2010;30:12589-12596.

24 Ishunina TA, Swaab DF: Decreased alternative splicing of estrogen receptor- $\alpha$ mRNA in the Alzheimer's disease brain. Neurobiol Aging 2012;33:286-296.e3.

-25 Petersen DN, Tkalcevic GT, Koza-Taylor PH, Turi TG, Brown TA: Identification of estrogen receptor beta2, a functional variant of estrogen receptor beta expressed in normal rat tissues. Endocrinology 1998;139:10821092.

26 Price RH Jr, Lorenzon N, Handa RJ: Differential expression of estrogen receptor beta splice variants in rat brain: identification and characterization of a novel variant missing exon 4. Brain Res Mol Brain Res 2000;80: 260-268.

-27 Price RH Jr, Butler CA, Webb P, Uht R, Kushner P, Handa RJ: A splice variant of estrogen receptor beta missing exon 3 displays altered subnuclear localization and capacity for transcriptional activation. Endocrinology 2001;142:2039-2049.

28 Weiser MJ, Foradori CD, Handa RJ: Estrogen receptor beta in the brain: from form to function. Brain Res Rev 2008;57:309-320.

-29 Sharma SC, Clemens JW, Pisarska MD, Richards JS: Expression and function of estrogen receptor subtypes in granulosa cells: regulation by estradiol and forskolin. Endocrinology 1999;140:4320-4334.

30 Chung WC, Pak TR, Suzuki S, Pouliot WA, Andersen ME, Handa RJ: Detection and localization of an estrogen receptor beta splice variant protein (ERbeta2) in the adult female rat forebrain and midbrain regions. J Comp Neurol 2007;505:249-267.

- 31 Rivier C, Vale W: Interaction of corticotropin-releasing factor and arginine vasopressin on adrenocorticotropin secretion in vivo. Endocrinology 1983;11:939-942.

- 32 Schlosser SF, Almeida OF, Patchev VK, Yassouridis A, Elands J: Oxytocin stimulated release of adrenocorticotropin from the rat pituitary is mediated by arginine vasopressin receptors of the V1b type. Endocrinology 1994;135:2058-2063.

- 33 De Kloet ER, Vreugdenhil E, Oitzl MS, Joels M: Brain corticosteroid receptor balance in health and disease. Endocr Rev 1998;19:269301.
4 Tsigos C, Chrousos GP: Hypothalamic-pituitary-adrenal axis, neuroendocrine factors and stress. J Psychosom Res 2002;53:865871.

35 Gaskin JH, Kitay JI: Adrenocortical function in the hamster. Sex differences and effects of gonadal hormones. Endocrinology 1970;87: 779-786.

6 Gaskin JH, Kitay JI: Hypothalamic and pituitary regulation of adrenocortical function in the hamster: effects of gonadectomy and gonadal hormone replacement. Endocrinology 1970;89:1047-1053.

37 Burgess LH, Handa RJ: Chronic estrogen-induced alterations in adrenocorticotropin and corticosterone secretion, and glucocorticoid receptor-mediated functions in female rats. Endocrinology 1992;131:1261-1269.

38 Viau V, Meaney MJ: Variations in the hypothalamic-pituitary-adrenal response to stress during the estrous cycle in the rat. Endocrinology 1991;129:2503-2511.

39 Serova LI, Harris, HA, Maharjan S, Sabban EL: Modulation of responses to stress by estradiol benzoate and selective estrogen receptor agonists. J Endocrinol 2010;205:253-262.

40 Ochedalski T, Subburaju S, Wynn PC, Aguilera G: Interaction between oestrogen and oxytocin on hypothalamic-pituitaryadrenal axis activity. J Neuroendocrinology 2007;19:189-197.

41 Ter Horst GJ, Wichmann R, Gerrits M, Wesenbroek C, Lin Y: Sex differences in stress responses: focus on ovarian hormones. Physiology Behav 2009;97:239-249.

42 Lund TD, Hinds LR, Handa RJ: $5 \alpha$-dihydrotestosterone and its metabolite, $5 \alpha$-androstan-3 $\beta, 17 \beta$-diol inhibit the hypothalamo-pituitary adrenal response to stress by acting through estrogen receptor beta expressing neurons in the hypothalamus. J Neurosci 2006;26 1448-1456.

43 Weiser MJ, Wu TJ, Handa RJ: Estrogen receptor beta (ER $\beta)$ agonist diarylpropionitrile (DPN): biological activities of $R$ - and $S$-enantiomers on behavior and hormonal response to stress. Endocrinology 2009;150: 1817-1825.

44 Suzuki S, Handa RJ: Estrogen receptor-beta, but not estrogen receptor-alpha, is expressed in prolactin neurons of the female rat paraventricular and supraoptic nuclei: comparison with other neuropeptides. J Comp Neurol 2005;484:28-42.

45 Simerly RB, Chang C, Muramatsu M, Swanson LW: Distribution of androgen and estrogen receptor mRNA-containing cells in the rat brain: an in situ hybridization study. J Comp Neurol 1990;294:76-95.

- 46 Estacio MA, Yamada S, Tsukamura H, Hirunagi K, Maeda K: Effect of fasting and immobilization stress on estrogen receptor immunoreactivity in the brain in ovariectomized female rats. Brain Res 1996;717:55-61.

47 Weiser MJ, Handa RJ: Estrogen impairs glucocorticoid dependent negative feedback on the hypothalamic-pituitary-adrenal axis via estrogen receptor alpha within the hypothalamus. Neuroscience 2009;159:883-895.
48 Bali B, Kovacs KJ: GABAergic control of neuropeptide gene expression in parvocellular neurons of the hypothalamic paraventricular nucleus. Eur J Neurosci 2003;18: 1518-1526.

49 Di S, Malcher-Lopes R, Marcheselli VL, Bazan NG, Tasker JG: Rapid glucocorticoidmediated endocannabinoid release and opposing regulation of glutamate and gammaaminobutyric acid inputs to hypothalamic magnocellular neurons. Endocrinology 2005;146:4292-4301.

-50 Somponpun SJ, Sladek CD: Osmotic regulation of estrogen receptor-beta in rat vasopressin and oxytocin neurons. J Neurosci 2003;23:4261-4269.

51 Hrabovszky E, Kallo I, Hajszan T, Shughrue PJ, Merchenthaler I, Liposits Z: Expression of estrogen receptor-beta messenger ribonucleic acid in oxytocin and vasopressin neurons of the rat supraoptic and paraventricular nuclei. Endocrinology 1998;139:2600-2604.

-52 Alves SE, Lopez V, McEwen BS, Weiland NG: Differential colocalization of estrogen receptor beta (ERbeta) with oxytocin and vasopressin in the paraventricular and supraoptic nuclei of the female rat brain: an immunocytochemical study. Proc Natl Acad Sci USA 1998;95:3281-3286.

53 Laflamme N, Nappi RE, Drolet G, Labrie C, Rivest S: Expression and neuropeptidergic characterization of estrogen receptors (ERalpha and ERbeta) throughout the rat brain: anatomical evidence of distinct roles of each subtype. J Neurobiol 1998;36:357-378.

54 Miller WJ, Suzuki S, Miller LK, Handa R, Uht RM: Estrogen receptor (ER) beta isoforms rather than ERalpha regulate corticotropin-releasing hormone promoter activity through an alternate pathway. J Neurosci 2004;24:10628-10635.

55 Whitnall MH: Stress selectively activates the vasopressin-containing subset of corticotropin-releasing hormone neurons. Neuroendocrinology 1988;50:702-707.

56 Bondy CA, Whitnall MH, Brady LS, Gainer $\mathrm{H}$ : Coexisting peptides in hypothalamic neuroendocrine systems: some functional implications. Cell Mol Neurobiol 1989;9:427-446.

57 Neumann ID: Involvment of the brain oxytocin system in stress coping: interactions with the hypothalamo-pituitary-adrenal axis. Prog Brain Res 2002;139:147-162.

58 Neumann ID, Torner L, Toschi N, Veenema AH: Oxytocin actions within the supraoptic and paraventricular nuclei: differential effects on peripheral and intranuclear vasopressin release. Am J Physol Regul Integr Comp Physiol 2006;291:R29-R36.

59 Kushner PJ, Agard DA, Greene GL, Scanlan TS, Shiau AK, Uht RM, Webb P: Estrogen receptor pathways to AP-1. Steroid Biochem Mol Biol 2000;74:311-317.

60 Lefstin JA, Yamamoto KR: Allosteric effects of DNA on transcriptional regulators. Nature 1998;392:885-888. 
61 Safe S, Kim K: Non-classical genomic estrogen receptor (ER)/specificity protein and ER/activating protein-1 signaling pathways. J Mol Endocrinol 2008;41:263-275.

-62 Vamvakopoulos NC, Chrousos GP: Evidence of direct estrogenic regulation of human corticotropin-releasing hormone gene expression. J Clin Invest 1993;92:1896-1902.

63 Safe S, Wang F, Porter W, Duan R, McDougal $\mathrm{A}$ : Ah receptor agonists as endocrine disruptors: antiestrogenic activity and mechanisms. Toxicol Lett 1998;102-103:343-347.

-64 Webb P, Lopez GN, Uht RM, Kushner PJ: Tamoxifen activation of the estrogen receptor/AP-1 pathway: potential origin for the cell-specific estrogen-like effects of antiestrogens. Mol Endocrinol 1995;9:443-456.

65 Kasckow J, Mulchahey JJ, Aguilera G, Pisarska M, Nikodemova M, Chen HC, Herman JP, Murphy EK, Liu Y, Rizvi TA, Dautzenberg FM, Sheriff S: Corticotropin-releasing hormone (CRH) expression and protein kinase A mediated $\mathrm{CRH}$ receptor signalling in an immortalized hypothalamic cell line. J Neuroendocrinol 2003;15:521-529.

-66 Mayer CM, Fick LJ, Gingerich S, Belsham DD: Hypothalamic cell lines to investigate neuroendocrine control mechanisms. Front Neuroendocrinol 2009;30:405-423.

-67 Ogura E, Kageyama K, Hanada K, Kasckow J, Suda T: Effects of estradiol on regulation of corticotropin-releasing factor gene and interleukin-6 production via estrogen receptor type beta in hypothalamic $4 \mathrm{~B}$ cells. Peptides 2008;29:456-464.

68 Jasnow AM, Schulkin J, Pfaff DW: Estrogen facilitates fear conditioning and increases corticotropin-releasing hormone mRNA expression in the central amygdala in female mice. Horm Behav 2006;49:197-205.

-69 Sawchenko PE, Swanson LW, Vale WW: Coexpression of corticotropin-releasing factor and vasopressin immunoreactivity in parvocellular neurosecretory neurons of the adrenalectomized rat. Proc Natl Acad Sci USA 1984;81:1883-1887.

70 Uht RM, McKelvy JF, Harrison RW, Bohn MC: Demonstration of glucocorticoid receptor-like immunoreactivity in glucocorticoid-sensitive vasopressin and corticotropin-releasing factor neurons in the hypothalamic paraventricular nucleus. J Neurosci Res 1988;19:405-411, 468-469.

-71 Foradori CD, Lund TD, Nagahara AH, Koenig JI, Handa RJ: Corticotropin-releasing hormone heterogeneous nuclear RNA (hnRNA) and immunoreactivity are induced in extrahypothalamic brain sites by kainic-acid-induced seizures and are modulated by estrogen. Brain Res 2007;1164:4455.

-72 Tian F, Hu XZ, Wu X, Jiang H, Pan H, Marini AM, Lipsky RH: Dynamic chromatin remodeling events in hippocampal neurons are associated with NMDA receptor-mediated activation of Bdnf gene promoter 1. J Neurochem 2009;109:1375-1388.
3 Smith JL, Freebern WJ, Collins I, De Siervi A, Montano I, Haggerty CM, McNutt MC, Butscher WG, Dzekunova I, Petersen DW, Kawasaki E, Merchant JL, Gardner K: Kinetic profiles of p300 occupancy in vivo predict common features of promoter structure and coactivator recruitment. Proc Natl Acad Sci USA 2004;101:11554-11559.

74 Shang Y, Hu X, DiRenzo J, Lazar MA, Brown $\mathrm{M}$ : Cofactor dynamics and sufficiency in estrogen receptor-regulated transcription. Cell 2000;103:843-852.

75 Metivier R, Penot G, Hubner MR, Reid G, Brand H, Kos M, Gannon F: Estrogen receptor-alpha directs ordered, cyclical, and combinatorial recruitment of cofactors on a natural target promoter. Cell 2003;115:751-763.

76 Lalmansingh A, Uht R: Estradiol regulates corticotropin-releasing hormone gene (crh) expression in a rapid and phasic manner that parallels estrogen receptor-alpha and -beta recruitment to a $3^{\prime}, 5^{\prime}$-cyclic adenosine $5^{\prime}$ monophosphate regulatory region of the proximal crh promoter. Endocrinology 2008; 149:346.

77 Bloch M, Schmidt PJ, Danaceau M, Murphy J, Nieman L, Rubinow DR: Effects of gonadal steroids in women with a history of postpartum depression. Am J Psychiatry 2000; 157:924-930.

78 Jacome LF, Gautreaux C, Inagaki T, Mohan G, Alves S, Lubbers LS, Luine V: Estradiol and ERbeta agonists enhance recognition memory, and DPN, an ERbeta agonist, alters brain monoamines. Neurobiol Learn Mem 2010;94:488-498.

79 Watson CS, Alyea RA, Cunningham KA, Jeng YJ: Estrogens of multiple classes and their role in mental health disease mechanisms. Int J Womens Health 2010;2:153-166.

80 Leret ML, Molina-Holgado F, Gonzalez MI: The effect of perinatal exposure to estrogens on the sexually dimorphic response to novelty. Physiol Behav 1994;55:371-373.

-81 Nomikos GG, Spyraki C: Influence of oestrogen on spontaneous and diazepam-induced exploration of rats in an elevated plus maze. Neuropharmacology 1988;27:691696.

82 Morgan MA, Pfaff DW: Effects of estrogen on activity and fear-related behaviors in mice. Horm Behav 2001;40:472-482.

83 Hewitt SC, Korach KS: Oestrogen receptor knockout mice: roles for oestrogen receptors alpha and beta in reproductive tissues. Reproduction 2003;125:143-149.

84 Ogawa S, Chan J, Chester AE, Gustafsson JA, Korach KS, Pfaff DW: Survival of reproductive behaviors in estrogen receptor beta gene-deficient (betaERKO) male and female mice. Proc Natl Acad Sci USA 1999;96: 12887-12892.
85 Ogawa S, Eng V, Taylor J, Lubahn DB, Korach KS, Pfaff DW: Roles of estrogen receptor-alpha gene expression in reproductionrelated behaviors in female mice. Endocrinology 1998;139:5070-5081.

86 Tomihara K, Soga T, Nomura M, Korach KS, Gustafsson JA, Pfaff DW, Ogawa S: Effect of ER-beta gene disruption on estrogenic regulation of anxiety in female mice. Physiol Behav 2009;96:300-306.

87 Lund TD, Rovis T, Chung WC, Handa RJ: Novel actions of estrogen receptor-beta on anxiety-related behaviors. Endocrinology 2005;146:797-807.

88 Walf AA, Frye CA: ERbeta-selective estrogen receptor modulators produce antianxiety behavior when administered systemically to ovariectomized rats. Neuropsychopharmacology 2005;30:1598-1609.

89 Walf AA, Rhodes ME, Frye CA: Antidepressant effects of ERbeta-selective estrogen receptor modulators in the forced swim test. Pharmacol Biochem Behav 2004;78:523529.

-90 Krezel W, Dupont S, Krust A, Chambon P, Chapman PF: Increased anxiety and synaptic plasticity in estrogen receptor beta-deficient mice. Proc Natl Acad Sci USA 2001;98: 12278-12282.

91 Walf AA, Koonce C, Manley K, Frye CA: Proestrous compared to diestrous wildtype, but not estrogen receptor beta knockout, mice have better performance in the spontaneous alternation and object recognition tasks and reduced anxiety-like behavior in the elevated plus and mirror maze. Behav Brain Res 2009;196:254-260.

\$92 Hughes ZA, Liu F, Platt BJ, Dwyer JM, Pulicicchio CM, Zhang G, Schechter LE, Rosenzweig-Lipson S, Day M: WAY-200070, a selective agonist of estrogen receptor beta as a potential novel anxiolytic/antidepressant agent. Neuropharmacology 2008;54:11361142.

93 Imwalle DB, Gustafsson JA, Rissman EF: Lack of functional estrogen receptor beta influences anxiety behavior and serotonin content in female mice. Physiol Behav 2005; 84:157-163.

94 Donner N, Handa RJ: Estrogen receptor beta regulates the expression of tryptophan-hydroxylase 2 mRNA within serotonergic neurons of the rat dorsal raphe nuclei. Neuroscience 2009; 163:705-718.

$\$ 5$ Oyola MG, Portillo W, Reyna A, Foradori CD, Kudwa A, Hinds L, Handa RJ, Mani SK: Anxiolytic effects and neuroanatomical targets of estrogen receptor- $\beta$ (ER $\beta$ ) activation by a selective ER $\beta$ agonist in female mice. Endocrinology 2012;153:837-846.

96 Rubino T, Sala M, Vigano D, Braida D, Castiglioni C, Limonta V, Guidali C, Realini N, Parolaro D: Cellular mechanisms underlying the anxiolytic effect of low doses of peripheral Delta9-tetrahydrocannabinol in rats. Neuropsychopharmacology 2007;32: 2036-2045. 